\title{
Brief Survey on Use of E-Banking in Albania
}

\author{
Ermela Kripa, PhD \\ European University of Tirana \\ ermela.kripa@uet.edu.al \\ Marinela Seitaj, MsC \\ Coordinator UET Language Centre/ IELTS test, European University of Tirana \\ Marinela.seitaj@uet.edu.al
}

Doi:10.5901/ajis.2015.v4n2p407

\section{Abstract}

E-Banking qualifies as an innovative service that combines the positive aspects of modern banking communication technology to bring a range of online banking services close to consumers and business. A significant proportion of banks in Albania provide their customers with such service, which reaches the level of developed countries. It is striking is that the usage level of this service compared with those countries is much lower. "The level of use of the E-Banking by individuals is in proportion to the investment made by the bank to enlarge the knowledge of this service in the market." The paper is based on a combination of observative analysis through questionnaires given to individual service users of E-Banking in Albania, and descriptive analysis, based on the literature related to this field of study. This paper is compiled based on quantitative and qualitative methods of scientific research, therefore, it has a mixed model of research methods.

Keywords: E-banking, The level of use of e-banking, Demographic profile of surveyors, Information channels, The frequency of the use of E-banking

\section{Introduction}

E-banking is a new phenomenon of banking services, for this reason previous data about its users are very uncommon. This is why we chose to compile and apply a questionnaire about the service to individuals. There would be plenty more data which would allow us to create a database on which we can argue about the extent and reasons for use. The questionnaire is presented in the form of online pollsters, since the users of this distribution channel happen to be internet users at the same time. The sample is composed of 152 surveyors and its type was: Random Probabilitiar. On the other hand, qualitative methods have been selected to evaluate the banks delivery service. Given that we want to look at the investment level and image management, as well as the introductory proccess of customers by banks, the most convenient way seems to be interviews with heads of E-banking department in major banks. This is because a quantitative method would wipe away the differences among banks regarding their strategy on promoting this service. We are interested to detect different details of each bank, so that we can understand if these changes lead to changes in behavior or approach of individual client towards e-banking.

In the last part of the paper, electronic payment instruments are recorded and it is given a detailed analysis, based on the questionnaire for E-Banking service given to individual users in Albania. Finally, there is a summary of key findings of the research.

\section{Literature Review}

The early electronic distribution started with the use of ATM's. The client could perform various actions through phone: he was able to reach the control center account, transfer money, ask for information on banking services or even pay various bills (Chaven, 2013).

The initial services that were offered were modest, such as information on account status and payment of various bills. It is clear that this kind of banking service did not fulfill all the client's needs, but it certainly paved the way for more comprehensive and sophisticated services that we are offered today (Shannak, 2013: 245).

Nowadays, that thanks to information and communication technology, E-Banking is a service spares the loss of 
valuable time due to traditional banking bureaucracy and also manages personal finances in the most efficient way, in a very short period of time.

In many studies E-banking is defined as a fully modern automatic service which brings to customers traditional banking products through information technology platforms and interactive communication. In 2005 the leading countries in providing banking services were England and eight other Western Europe countries, mainly France, Spain, Portugal, Germany, Switzerland, the Netherlands, Luxembourg and Scandinavia (Issah, 2011).

In our time, E-banking has become an element for the survival of banks in the market. Customers see this service as convenient, safe and reliable for carrying out banking transactions. Banks spend considerable sums for years to win the trust of customers and they would not jeopardize this confidence by creating incomprehensible websites that lead costumers to disorientation. On the other hand, banks use such services as a competitive advantage and a method to efficiently expand their business beyond geographical barriers (Shannak, 2013: 245).

Meanwhile, various research indicates that E-Banking serves as a strategic tool to reduce costs in the banking sector. Shah \& Clarke (2009) has shown that the use of "e-banking" reduces costs. It introduces us to the fact that electronic services cost less compared to the services offered at the counters of the bank. It is also worth mentioning that the greater the client base is, the lower the transaction costs will be, given that fixed costs are higher than variable costs.

Studies show that the e-banking distribution depends more on consumer acceptance than the bids placed by banks. Before deciding to use e-banking service, it is important for the individual to be informed of the benefits, safety and risk issues which accompany this service (Safeena, et al., 2011: 56). Information technology services are considered as key drivers of major and most important changes that are happening worldwide. Certainly, transition from traditional banking to E-banking makes a huge difference. On the other hand, consumers have become more susceptible to digital technology, therefore banks must continually bring innovation to suit the needs of clients. Banks, captured under the pressure of competition with each other to capture most of the banking market, have begun to present the distribution channel of their products through the Internet (Munusamy et al., 2012). Internet services industry in general and the banking industry in particular are used as a tool to improve the quality of service delivery. E-banking service helps banks retain and build closer relationships with customers.

\section{Observative analysis on the use of E-banking in Albania}

E-Banking is an innovation which combines new information technologies with traditional banking services. Thanks to this service, operating costs are reduced and earned income is increased. Basically E-Banking is defined as the Internet selfservice. It is exactly why electronic banking, through a relationship management, helps customers transit from expensive choices and telephone services, to these types of self-services.

Implementation of E-Banking by banks is associated with improved performance in terms of growth of assets, reduction of costs, increase of the portfolio. Studies have shown that the creation of virtual banks, not only establishes a new channel of distribution of banking services, but also creates added value for the client and the financial institution (Yang, et al., 2009: 238).

E-banking ofron përfitime për të dyja palët si për institucionin bankar dhe për konsumatorin. E-banking offers benefits for both sides, the banking institution and the customer. Various studies have identified the main benefits for banks thanks to the delivery of this service to the customers. These benefits include the reduction of operational costs, reaching new segments of the population, efficiency, an increase of the bank reputation and also a notable improvement of customers service. The banking system has begun to seriously take into consideration online services, which are no longer seen as a luxury, but a necessity that must be met in the best way possible. In the recent years, banks in our country have created their online outlets offering electronic services to clients. In fact, the banking model in our country is presented as a model that combines both physical and online branches, offering more and more choices for the users. Since E-banking is a new phenomenon of banking services, it is unlikely to find earlier data about individuals who use this service. This is why we chose to compile and apply a questionnaire about the service to individuals. There would be plenty more data which would allow us to create a database on which we can argue about the extent and reasons for use.

The sample is composed of 152 interviewers. The questionnaire is presented in the form of online pollsters, since the users of this distribution channel happen to be internet users at the same time. The questionnaire consists of questions on demographic character such as age, sex, residence, income, status, the use of compuer for work or nonwork reasons. After that, the questions raised are on the frequency of visiting a bank branch, using the ATM, the performance of online shopping during the last twelve months, as well as on the activities carried out online. Furthermore, 
the questionnaire is followed by questions about E-Banking services as regards the information of the service, its use or not, the period of use, etc.

In the end, the questionnaire is closed by a group of questions on the used bank, the reasons for choosing this bank, reasons for using E-Banking service, as well as the identification of transactions on which this service is used.

\subsection{Individuals and the level of use of E-banking in Albania}

\subsubsection{Demographic profile of surveyors}

Table 1.1 : Participating ages in the questionnaire

\begin{tabular}{|c|c|}
\hline Age & \\
\hline$<25$ & $25 \%$ \\
\hline$>60$ & $1 \%$ \\
\hline $\mathbf{2 5 - 4 0}$ & $62 \%$ \\
\hline $\mathbf{4 0 - 6 0}$ & $13 \%$ \\
\hline
\end{tabular}

Out of 152 surveyors, $62 \%$ of them are aged from 25 to 40 years old and $25 \%$ of surveyors are aged under 25 years. Meanwhile, pollsters aged 40-60 years old are only 13\%. This data shows that the younger generation has more access to electronic banking services compared to older generations. This is because of their knowledge of modern technology, especially regarding the positive aspects that brings the use of electronic banking services. The table below shows percentages that every age group occupies in the survey.
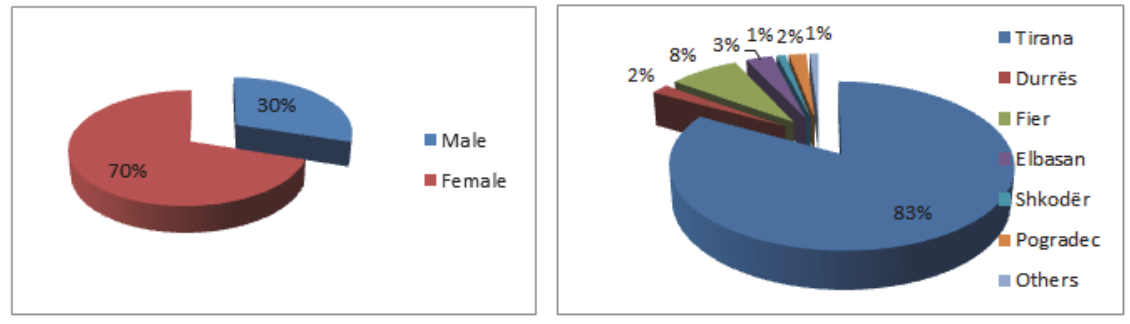

Graph 1.2: Pollsters sex and location

Regarding the questions of the questionnaire containing demographic character, it showed that females appear at a level of $70 \%$ of respondents. While males percentage is $30 \%$. Such a result is not surprising given the fact that women are leaders in online shopping. The above graph clearly illustrates the gender ratio stands among interviewers.

Table 1.3: Pollsters' status

\begin{tabular}{|l|c|}
\hline Unemployed & $7 \%$ \\
\hline Employed & $73 \%$ \\
\hline Retired & $1 \%$ \\
\hline Student & $20 \%$ \\
\hline
\end{tabular}

As seen from the chart above, most of the respondents (83\%) are residents in Tirana. E-banking is a service designed for individuals who have a certain level of income, education and financial culture. In these conditions, Tirana is the district in which is concentrated that part of the population, characterized by a high standard of living compared with other districts. This in terms of income level, education, access to modern technology, more information on banking products, individuals who need such a service because of commitments during the day. Also, Tirana is the metropolis in which most of the businesses which operate in different areas in the country are located, and therefore the use of the computer during work hours allows more transactions. To give a clearer picture of the status of pollsters that have become part of this survey, we use the table above. What I noticed is that $73 \%$ of respondents hold the status of employees, $20 \%$ of them hold the 
student status, $7 \%$ appear as unemployed and $1 \%$ as retired. Individuals who are employed are more likely to appear as users of this service. Limited time brings to the need to reduce the physical contact with the bank.

Queues to pay a bill, to perform a banking transaction or to transfer funds within and outside the country often become stressful when they are not carried out in proper terms. For this reason, technology seems to be very helpful. EBanking is a service that saves time and provides safety at a lower cost, satisfying the needs of individuals.

Table 1.4: Monthy income of pollsters

\begin{tabular}{|l|c|}
\hline Monthly income & \\
\hline$<21000$ & $9 \%$ \\
\hline$>168000$ & $17 \%$ \\
\hline $\mathbf{2 1 0 0 0}-\mathbf{4 2} 000$ & $13 \%$ \\
\hline $\mathbf{4 2 0 0 0}-\mathbf{9 8 0 0 0}$ & $39 \%$ \\
\hline $\mathbf{9 8 0 0 0}-\mathbf{1 6 8 0 0 0}$ & $22 \%$ \\
\hline
\end{tabular}

The table above shows that most of the respondents belong to an average or high level of monthly income. Individuals with income from 42'000-98'000 make up 39\% of the respondents, followed by those individuals, whose level of income varies from $98^{\prime} 000$ to $168^{\prime} 000$. It is worth mentioning that the income factor has a direct impact on the use of online banking services. Higher income means higher opportunity to access computers, more access to the Internet, more opportunities to conduct online purchases. All of these are characteristics of the e-banking service users.

Table 1.5: The hourly use of the computer in a week/ non-work related

\begin{tabular}{|l|c|}
\hline Hours spent on PC/week/non-work & \\
\hline$<$ Less than an hour & $17 \%$ \\
\hline $\mathbf{1 - 5}$ hours & $37 \%$ \\
\hline $\mathbf{1 0}-\mathbf{2 0}$ hours & $16 \%$ \\
\hline $\mathbf{5}-\mathbf{1 0}$ hours & $22 \%$ \\
\hline More than 20 hours & $7 \%$ \\
\hline
\end{tabular}

The above results show that $37 \%$ of the respondents use the computer for 1-5 hours per week to perform activities that are not related to work. About 22\% of respondents spend 5-10 hours per week in front of the computer for non-work purposes. Respondents that remain in front of a computer 10 hours to 20 hours for the above purposes are at $16 \%$. To view the relationship that exists between staying in front of the computer during the week for non-work purposes with the use of E-Banking service, we drafted a report between these two variables. Results will appear below.

Table 1.6:The hourly use of the computer in a week/ work related

\begin{tabular}{|l|c|}
\hline Hours spent on PC pc/week/work & \\
\hline$<$ Less than an hour & $9 \%$ \\
\hline $\mathbf{1 - 5}$ hours & $15 \%$ \\
\hline $\mathbf{1 0}-\mathbf{2 0}$ hours & $16 \%$ \\
\hline $\mathbf{5}-\mathbf{1 0}$ hours & $17 \%$ \\
\hline More than 20 hours & $42 \%$ \\
\hline
\end{tabular}

The table above shows that $42 \%$ of individuals that have become part of the survey spend more than 20 hours in front of the computer in a week to perform activities related to their work. The proportion of individuals who remain on the computer 5 to 10 hours for work purposes is $17 \%$.

Meanwhile, the table shows that only $9 \%$ of respondents spent less than 1 hour per week in front of the computer, in order to carry out activities related to the work. The relationship that we have built between two variables, PC work hours per use of E-Banking service, will help us to better understand how their ratio stands. Results will appear in a separate section. 


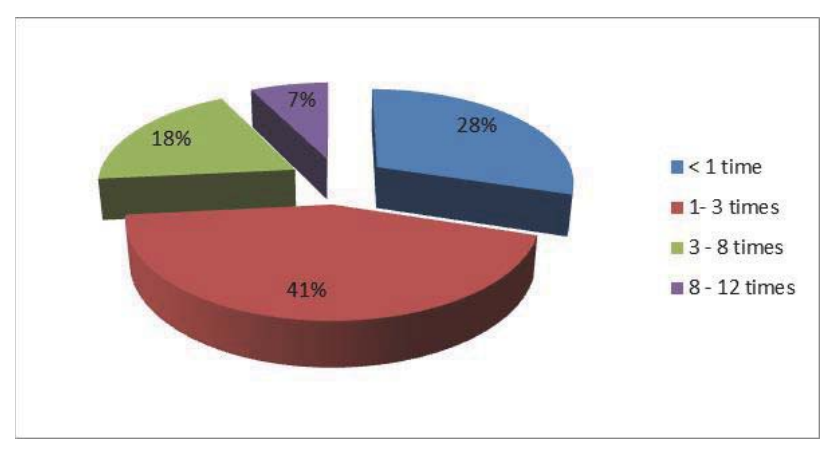

Graph 1.7: The frequency of visiting a bank per month

Regarding the question in the questionnaire on the frequency of visiting individual bank branches during a month, the pollsters responded that $41 \%$ of them showed up at the counter of the bank 1-3 times a month. As indicated by the chart above, individuals who visit the a bank once a month count at around $28 \%$ out of the total. Different percentages shown in the graph, depending on the number of times the individual shows up at the counter of the bank during the month, proof the skeptical nature of our society to such technological changes. This shows that individuals prefer to perform different actions by the physical bank branch rather than use home banking or phone services.

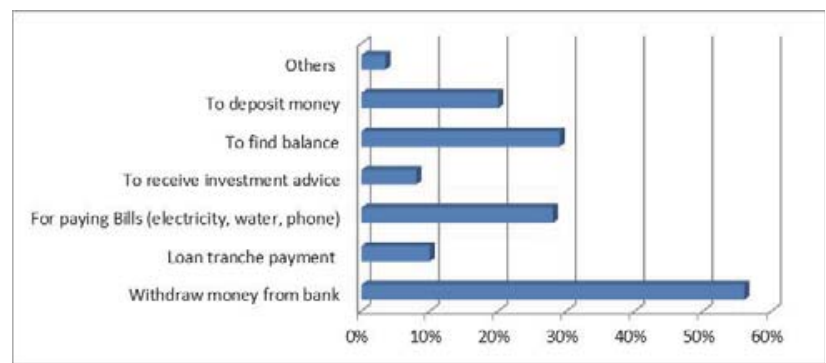

Graph 1.8: Reasons for which the client visits a bank

Banks in our country offer numerous possibilities in terms of Internet Banking service. Basic service packages offered by most banks include: information on balances and accounts, reports over a period of time as well as other services such as electronic invoices, transfert of funds to different accounts, foreign exchange etc. Study results show that most of the individual users prefer visiting a physical branch bank to withdraw money, to get informed on the balance, as well as to pay bills (electricity, water, telephone). These results show once again that customers prefer to use banking services by the branch rather than from home via Internet, phone.

What we may say is that the massive increase of the use of e-banking services from the individual will come when the clients become aware of the advantages that such services offer. However, clarification of client's needs would demonstrate the positive effects of the use of this innovative service.

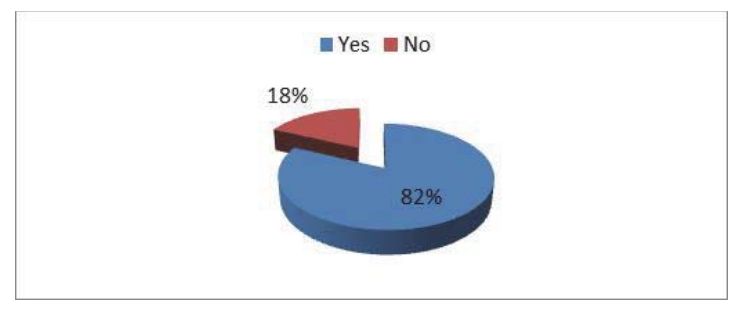

Graph 1.10: Familiarity of clients with E-banking service

The survey data show that even though e-banking is a relatively new concept, especially for our country, it was shown that this service is quite well-known to Albanian customers. About $82 \%$ of respondents are familiar with the service and 
$18 \%$ of them have no information about it. The high level of recognition for service is related to the fact that individuals are clients of the bank and E-Banking service is presented by bank employees. By presenting to the customers the advantages, comfort, safety and the well-functioning of the service, employees of the bank will affect the growth of trust at individuals for such banking technology.

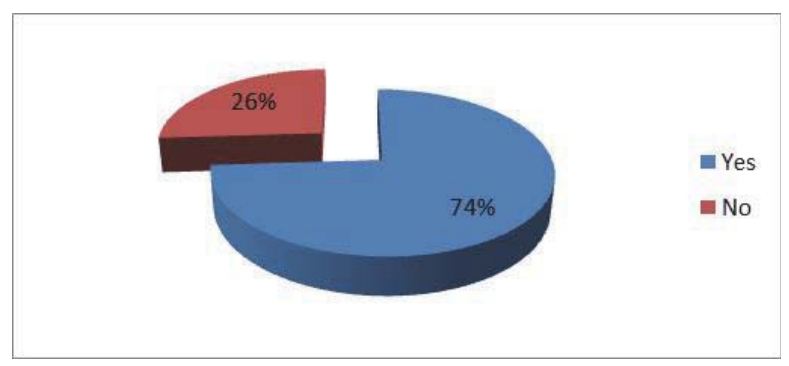

Graph 1.11: Levels of usage of E-Banking service by individuals

One of the important and concrete questions that interviewers addressed as part of the questionnaire was whether they use the E-Banking service. As seen from the chart above, $74 \%$ of the respondents are users of this service and the level of individual non-users of this electronic service presented to $26 \%$. As the e-banking is a relatively new service in our country, it was noted that individuals have been mainly using this service during the last two years.

In this sense, the improvement and growth of users of these services has been recorded during the last three years. Statistics on the level of information on e-banking service and its use, show us a relatively low level of use of this service by individuals. The reasons that explain this low rate of usage were: low consumer confidence and the modest culture of the use of the financial system. The skeptical nature of the Albanian customer to accept such changes highly impacts the use of this innovative service.

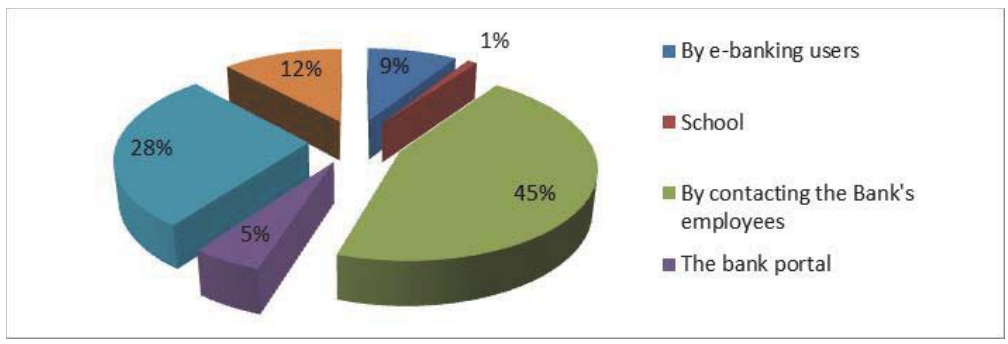

Graph 1.12: Channels of information on E-Banking service

Banks try to provide services which are closer to the customers demand. Marketing is an important tool, which banks use to transmit to the client a sense of what differentiates one bank from the others and also, the reasons why one bank must be chosen instead of other banks. The survey data showed that $45 \%$ of customers were informed about this service by employees of the bank. Another important channel after the bank itself, seems to be: websites. About $28 \%$ of the respondents were informed about this service through its website. What displays as disturbing is the low percentage of current users that suggest this service to other individuals, about $9 \%$ of the respondents. It is worth mentioning that the bank should focus more on the promotion of products and services by identifying the advantages the use of these services for both sides. On the perspective of banks, the promotion of electronic banking services should be based on the characteristic elements and its ease of use. One of the barriers that affects the use of this service is the mentality and the use of traditional banking, physical contact with the bank counters. At this point it is worth mentioning that bank employees should be informed more about these new services, as this would result in changing the perception of customers and a sales increase for these services. The increase of information level about these services, various awareness campaigns, awareness to the client, as well as a trust increase of the clients towards such banking technologies, all of these would change the level of use by the Albanian client. 


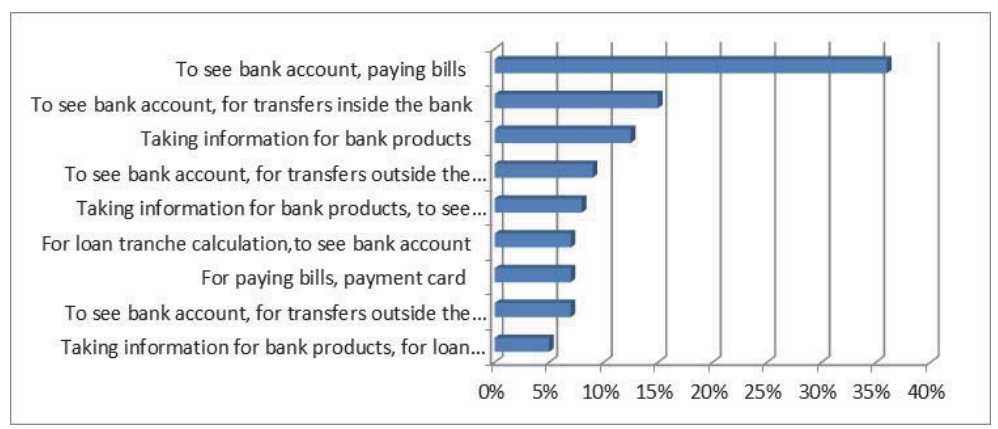

Graph 1.13 : The types of transactions for which the client uses E-Banking service

Study results show that the client focuses its use of E-Banking service mainly to check his account balance and to pay various bills. As mentioned above, the banks offer a package of services. Limited use of only a few specific services is explained by the fact that the receipt of such services has negligible cost to the client. Registration and checking of account are free, but if the client wants to perform transfers in between accounts or other additional services, additional commissions are required. The costs of using a specific service appear different and vary depending on the services that the customer chooses to use.

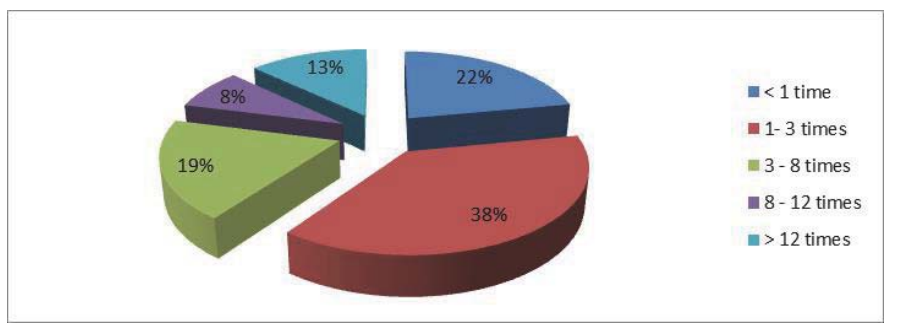

Graph 1.14: The frequency of ATM use by individuals

ATM services, compared with other electronic products, were provided earlier in our banking system. This has led to a gain of experience at the ATM by the service customers, an increase in the level of confidence and love towards this service. Mostly, customers use ATMs for cash withdrawal. The above graph shows that $38 \%$ of respondents use the ATM services about 1-3 times per month, $13 \%$ of them use this service 8-12 times per month. The massive use of ATM is linked to facilities that it offers, such as service schedules for cash withdrawal at any time of the day.

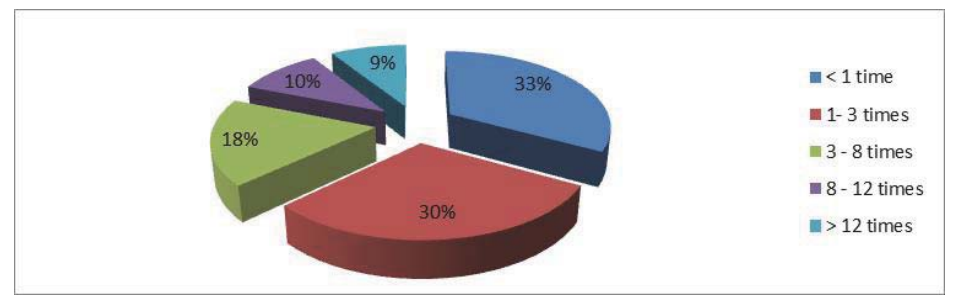

Graph 1.15: The frequency of online shopping over the past 12 months by the individual

Statistics presented above related to the frequency of online shopping from the users of e-banking service indicate that about $33 \%$ of individuals made one online purchase in the last twelve months. Meanwhile, $30 \%$ of the respondents have conducted online purchases 1-3 times in the last 12 months. Only $9 \%$ of respondents have conducted online purchases more than 12 times during the past 12 months. What we may say, is that individuals who have mid-level or high-level income, are more informed on the procedures and they use online shopping quite frequently. 

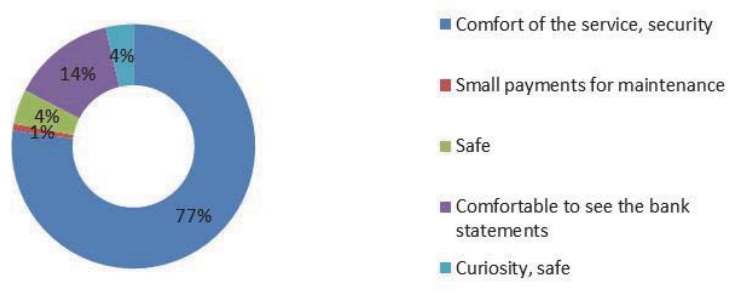

Graph 1.16: Reasons for the use of E-Banking by individual

Individuals have been asked for the advantages of the use of E-banking, considering their own personal experience. About $84 \%$ of users appreciate this service mostly for the comfort it offers as a service. A tiny part of the pollsters, almost negligible, uses this service for security issues. Time is one of the most precious things to everyone. In this sense, it is sometimes impossible to accomplish all the things within certain limits. Precisely for this E-Banking serves and is also highly evaluated, for the comfort it offers, this in the sense that wherever you are, in the office, at home or while traveling, the bank is always with you without limit. One of the factors considered as influential on the use of E-Banking service to the foreign user is, exactly, the comfort it offers. On the issue of security, the banks in our country are trying to provide secure online services. Details of each client are protected by special security systems. In fact, cyber security is one of the most troubling problems the banking system is facing nowadays. Internet always allows space to attack personal data, despite the fact that banks invest a lot in strong defensive systems. Security issues and the identification of EBanking service as too complicated, these are some of the findings of this study in the context of the grounds of non-use of this service.

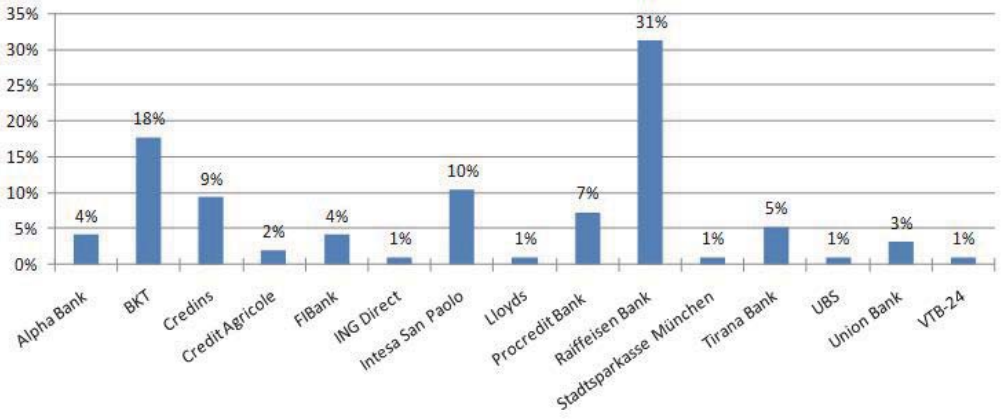

Graph 1.17: Banks in which customers use E-Banking service

The table above shows the banks in which individuals that are part of our research work use the E-Banking Service. Banks that stay on top of the list are: Raiffeisen Bank (31\%), BKT (18\%), Intesa Sanpaolo (10\%), Credins (9\%), ProCredit Bank (7\%), Tirana Bank with (5\%), Fibank (4\%).

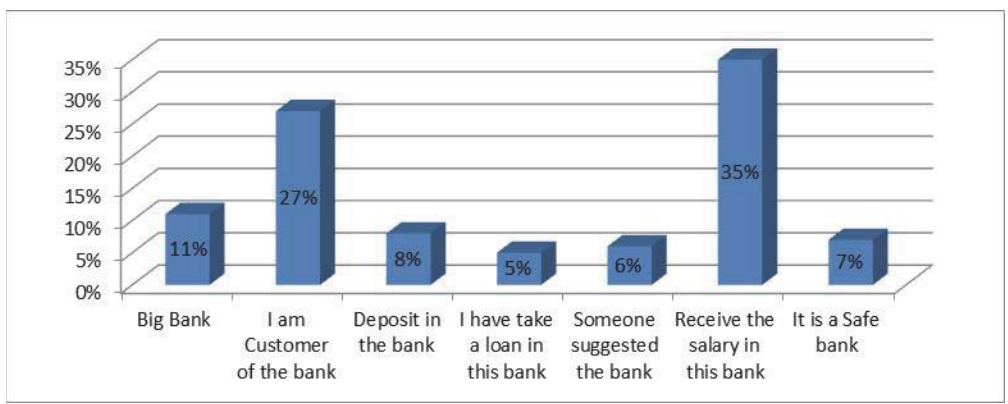

Graph 1.18: The individual reasons for choosing the use of E-Banking 
Regarding the question of why this bank was chosen, pollsters have displayed some variants that appear above in the graph illustrating the reasons for selecting the bank. It is showed that the individual chooses to use E-Banking service at the same bank in which his monthly salary exceeds. About $35 \%$ of E-Banking users choose the same bank in which they exceed their monthly salary due to the fact that the bank offers this service to these clients for almost no cost. Today's customers choose that bank which offers quick service and good quality, comfort, safety, and low costs. The chart noted that $27 \%$ of the respondents choose one of our system banks that offer online banking services, simply for the fact that he is a client of this bank. Bank staff tries to provide each client with the necessary information on the benefits of the use of e-banking, all about procedures and safety issues. However, for bank customers who decide to opt to use electronic services in addition to the usual services, banks apply negligible commissions and other facilities with a clear intention to increase the number of users of these new services.

In view of the customer, the use of E-banking with the same bank in which the individual worked before would be more comfortable, more receptive to innovative technologies in the banking system. At some of these banks, we have realized semi-structured interviews to understand the strategies that these banks use related to the new services, how they increase the level of use of customers, in order to turn these new services on their next success.

To receive clearer information on the factors that push the individual to use E-Banking service, we found different relations with variables such as age, income, housing, stay on the computer for work purposes or not, the way the individual was informed about E-Banking service etc. Through these relations, we want to identify which is the age that mainly uses the e-banking service, whether it masculine or feminine gender which dominates the level of usage of ebanking, how staying on the computer influences the whole process, whether it is for work purposes or not, as well as ways of informing on this relatively new service; all of these show a positive correlation with the level of use. To answer the above mentioned dilemmas, we use the results generated from each report.

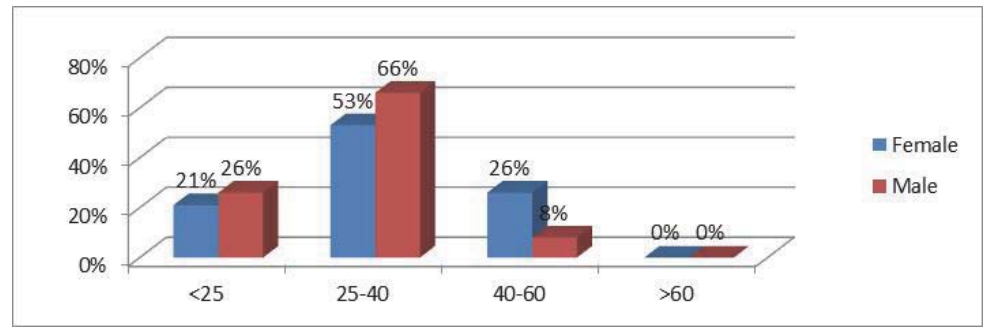

Graph 1.19: Use of E-Banking in terms of age

The graph shows that users of e-banking service are aged 25-40 years. It is understood that the users of this innovative service will not be very, either very old, for example, aged over 60 years. Using this service requires access to modern technology, minimum computer skills, financial culture regarding the recognition of products and services offered by the banking system in our country. These are some of the characteristics that describe a user of online services and features that are reflected mostly in the age group of $25-40$ years.

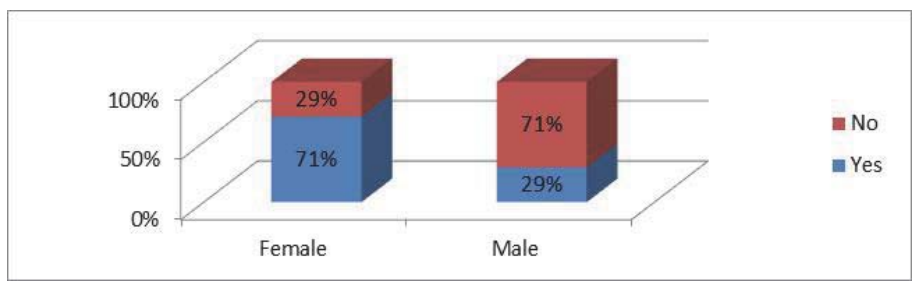

Graph 1.20 Use of E-Banking in terms of gender

The relation between sex interviewers and their use of E-Banking service has issued these results. Levels of E-Banking service usage appear higher for women, at a level of $71 \%$ against males that use this service to the extent of $29 \%$. An explanation of the pronounced difference between sexes is the fact that women, by their very nature, spend more time on the Internet to conduct online purchases of the most diverse. Consequently, it makes females appear as the main users of this service. 


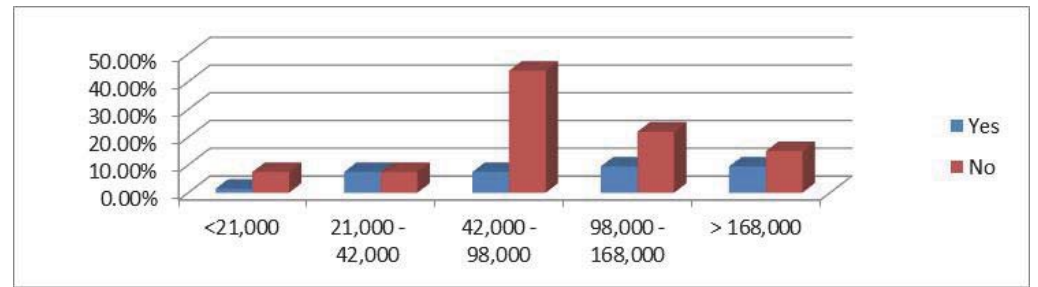

Graph 1.20: Use of E-Banking in terms of income

Income is an important factor affecting the use of online banking services. To understand the income level of the users of these online services, we have established a relationship chart between the level of income and the use of E-Banking service. As indicated by the chart above, the user e-banking service is the average-income individual, whose income ranges from 42,000 to 98,000. Income level is a living standard indicator. Average and high level of income shows that individuals have the opportunity to dispose a computer and also have the ability to use it, have access to the Internet, have information about the range of products and services that set the domestic banking system available to the client, awareness of the opportunity to perform online shopping, etc.

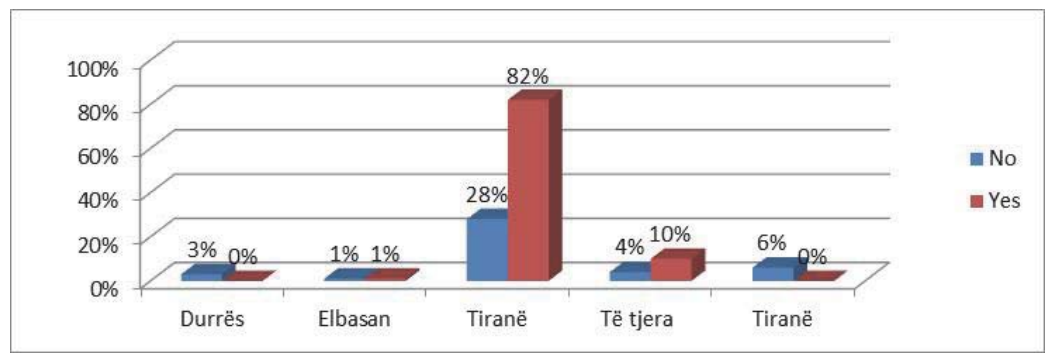

Graph 1.21: Use of E-Banking in terms of location

The relation chart between the individuals' location and their use of E-Banking service has clearly shown that individuals who are currently living in Tirana show a higher level of use of E-Banking service. Such results are expected in Tirana, because most of the population is concentrated there, and so are also the most powerful businesses, which because of the numerous commitments during the day consider this service as a necessity in their work. Tirana is where individuals have a different economic culture, characterized by advanced education, cognition of the latest technology and more interest in using services that improve their everyday life.

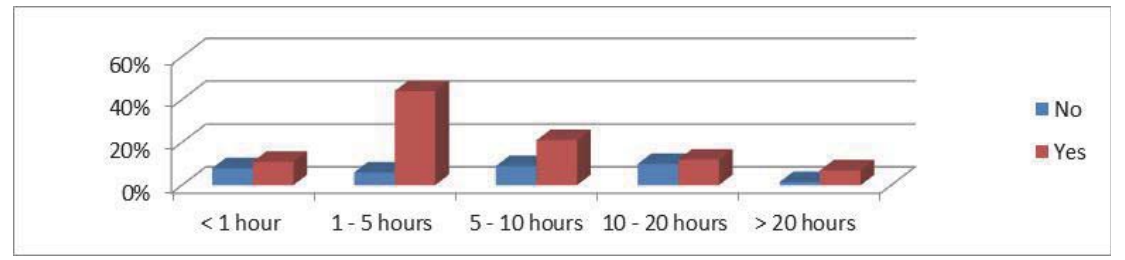

Graph 1.22: Use of E-Banking depending on the use of PC/week/non-work related

It is interesting to see how the use of computer during the week to perform activities not related to work, is closely linked to the use of E-Banking service. The relationship between these two variables has shown that individuals who spend 1 hour to 5 hours in front of the computer during the week to perform activities that are not intended for everyday work, make up the highest number of users of this service online. This shows that individuals, while remaining on the computer, can be informed about their account balance, credit card, money transferts, can perform the payment of various bills, online purchases, request information about loans, deposits, exchange rates etc. All these services are available to individuals thanks to the technology of E-Banking. 


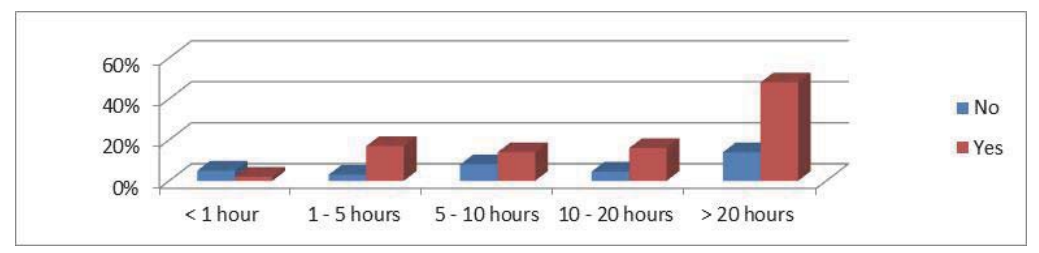

Graph 1.23 : Use of E-Banking depending on the use of PC / week / work related

On the other hand, it seems of great interest specifying the kind of relationship between the individual use of the computer for work purposes and the level of use of E-Banking. The report has shown that individuals who spend more than 20 hours per week on the computer to carry out activities related to the daily operations, use more online services compared to individuals who spend less time in front of the computer in their work environments. It is understandable that individuals who stay longer in their work environments, during this time, they manage to somehow use computers and the Internet, which allows them to perform various banking operations online, saving time and money.

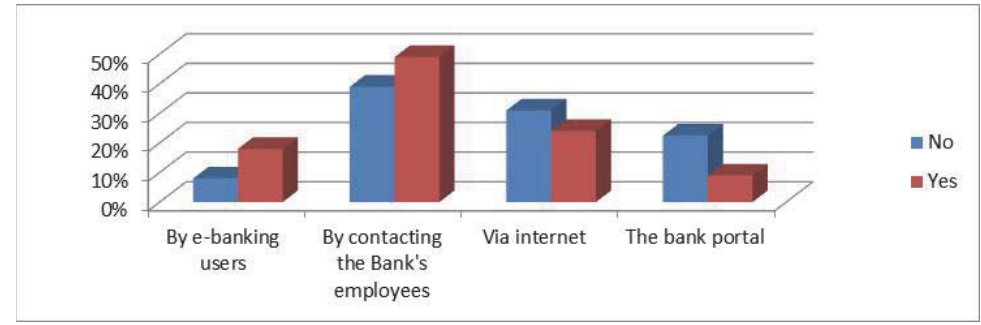

Graph 1.24: Use of E-banking depending on the level of recognition

The correlation between the level of use and the various news channels that the bank uses in order to increase the level of recognition to individuals for this service has a special significance for our thesis. Results indicate that individuals contacted by the staff of the bank seem to be the most loyal and frequent users of these services in comparison to other individuals who have been informed by other channels. The Bank should work more with the promoters relating to customer service by building specific strategies that engage all necessary marketing tools. Marketing of this service by the staff of the bank alone is not sufficient in this development stage the service is. More complex marketing strategies are required in order to increase awareness of the Albanian client for this service, clarify everyday needs, and bring a higher number of users of this service in the banking system.

\subsection{Summary of the study}

The recent financial innovations have demonstrated a significant impact on the way financial services are delivered to the customer today. The hypothesis raised in this paper has to do with the fact that the level of use of the E-Banking by individuals is in proportion to the investment made by the bank to increase the recognition of this service in the market. The above analysis showed that banking products are indeed moving towards development, but there are still a few barriers that keep these services away from their users. The level of the individual consumer usage is considered quite low. On the other hand, banks, as providers of these services, are presented without a clear strategy in terms of ways in which this service shall become a common service for all. E-Banking, as a new distribution channel, shows the need for further developments in terms of attracting the customers towards it.

\section{Conclusions}

Once we are done analyzing the factors that affect the use of E-Banking, the conclusions that come up are as follows:

- Electronic Banking is important for the economic development, due to its ability to create liquidity in the economy through its role as mediator.

- The most important factors that affect the use of E-Banking service by the individual include comfort, efficiency, perceived usefulness, price, security of transactions, the image of the bank, the services that banks 
offer etc.

- Electronic services offered in our country, although less sophisticated, can be compared to with services offered in developing countries.

- Internet banking is a well-recognized service by most of the customers in our country.

- E-Banking is important as a service, because it saves time, costs and is not limited in space.

\section{References}

\section{Main sources}

Questionnaire on E-banking

\section{Other sources}

Chaven, J. (2013). Internet Banking-Benefits and challenges in an emerging economy. International Journal of Research in Business, Vol 1, ISSUE 1, pp. 19-26.

Issah, S. (2011). Factors Affectors Affecting Adoption on Internet Banking. A case study of diamond trust bank individual costromers of kampala district branches. pp.11-12.

Munusamy, J., Annamalah, S., \& Chelliah, Sh. (2012). A Study of Users and Non-Users of Internet Banking in Malaysia. International Journal of Innovation, Management and Technology, Vol. 3, No. 4, pp 452, (http:/lijimt.org/papers/274-M610.pdf).

Shah, M., \& Clarke, S. (2009). "E-banking Management: Issues, Solutions, and Strategies Information Science Reference". New York: pp. $11-65$.

(http://www.newagepublishers.com/samplechapter/001636.pdf)

Safenna, R. (2010). "Customer Prespectives on E-Bussines Value: Case study of Internet Banking", Vol 15. No.1. pp.2. (http://www.arraydev.com/commerce/jibc/2010-04/Rahmath\%20Safeena.pdf).

Shannak, R. (2013). "Key Issues in E-Banking strengthes and weaknesses: The case of two Jordanian banks", European Scientific Journal, Vol, 9, NO. 7, pp. 245 (http://www.eujournal.org/index.php/esj/article/view/867/910)

\section{Anex A}

Questionnaire - E - banking - Individual

This questionnaire is designed to better comprehend the Internet users, their experience with e-banking as well as their expectations from this type of service. According to this questionnaire, there will be published results, obtained and measured data.

Thank you for your participation in this survey.

Required

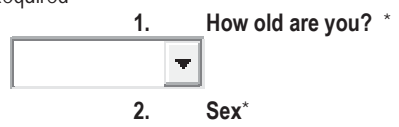

C Female

C Male

3. You actually live in *

Please, write down the name of the city where you live, no matter where you work or study

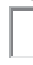

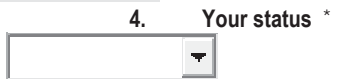

5. Please describe your family gross income *

Deriving from wages, pensions, scholarships, rents, income from property, unemployment benefits etc.
C $<21000$
C21000-42000
C $42000-98000$
C $98000-168000$
C $>168000$

6. How many hours do you spend in front of a computer for non-work purposes in a week *
C Less than 1 hour
C 1 - 5 hours 
$\begin{array}{ll}\text { C } & \text { 5-10 hours } \\ \text { C } & 10-20 \text { hours } \\ \text { C } & \text { More than } 20 \text { hours }\end{array}$
L Less than 1 hour
C 1 -5 hours
C 5 - 10 hours
C $10-20$ hours
C More than 20 hours

7. How many hours do you spend in front of a computer for work purposes in a week *
8. How often do you visit a bank during a month *
C $<1$ time
C 1 - 3 times
C 3 - 8 times
C. 8 - 12 times
C $>12$ times

9. What is the reason for visiting a bank branch *

Please, choose the most relevant reason

C To deposit money

C To ask for advice for investment opportunities

Co check the balance

C To withdraw money

C To pay bills (elektricity, water, telephone)

To pay the loan

O Other:

10. How often do you use ATMs during a month? *
C $<1$ time
C 1 - 3 times
[- 3 times
C 8-12 times
C >12 times

11. Approximately, how many times have you done online purchasing during the last 12 months? *
C <1 times
C 1-3times
C 3-8 times
C 8 -12times
C >12 times

12. Please, note down the activities you have performed online recently *

$\Gamma \quad T a x$ payment

Tax payment

$\ulcorner$ Purchase / Selling of financial services

$\Gamma \quad$ Online purchasing

$\Gamma \quad$ None

$\Gamma$ Other: 


\section{Do you agree with the following statements: *}

Totally Agree Neutral Do not Do not agree at agree

I agree to give
I agree to give
I agree to give
I agree to
information is
I agree to gi
page is secu
C Yes
No

15. How did you hear about the E-banking product? *

Please, select more than just an answer

$\ulcorner$ You have been personally contacted by the bank employees

$\ulcorner$ Via internet

$\ulcorner$ Via advertisements at the bank's website

$\ulcorner\quad$ Via advertisements in printed media

$\ulcorner$ Via advertisements in visual media

ᄃ At the bank's portal

$\ulcorner$ From another E-banking user

$\ulcorner$ Other:

16. If yes, have you eventually become an e-banking user? *

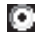

Yes

No

17. If not, list two main reasons.

18. If yes, for how long have you been using E-banking service? *

Less than a year

[- 1 - 2 years

C 3 - 5 years

C Other:

19. Which of the descriptions below best describes your actual situation?

C

The Bank offers a computer program which runs on your computer, and you access them through the bank's server and perform various transactions

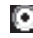
Use the site to enter your personal website that is provided by the bank program, and perform necessary transactions through it

C

None of the above

20. Which bank do you prefer for this service? *

21. According to you, what are the main advantages of using E-banking? *

Comodity (24 hour services)

Curiosity

Safety

Lower cost of maintenance

Easier to access the bank account and to check my banking transactions

Other:

22. For which of the following transactions do you use E-banking? *

To get information on bank products

To compute the monthly loan

To check my bank accounts

To apply for consumer's loan

For transferts within the bank

For transferts outside the bank

To pay the bills

Other: 